\title{
Urban Ecology of Triatoma infestans in San Juan, Argentina
}

\author{
Silvana L Vallvé/+ , Héctor Rojo*, Cristina Wisnivesky-Colli**
}

Instituto y Museo de Ciencias Naturales, Facultad de Ciencias Exactas, Físicas y Naturales, Universidad Nacional de San Juan, Avda. Libertador San Martín 315 (Oeste) - 5400 San Juan, Argentina *Municipalidad de la Capital de San Juan **Unidad Ecología de Reservorios y Vectores de Parásitos, Departamento de Ciencias Biológicas,

Facultad de Ciencias Exactas y Naturales, Universidad de Buenos Aires

This study was performed in an urban neighborhood of the capital city of the province of San Juan, Argentina. Erected as a housing complex, the place consists of 768 flats distributed in buildings of three and seven floors each. A survey was carried out in $33 \%$ of the dwellings, enquiring about the number of Triatoma infestans found indoors, stage of the bug development - nymph or adult - and how these insects had entered their homes. Adult T.infestans were found on all floors; 163 people (64\%) had found them at least once, and $130(51 \%)$ several times.

Dispersal flight seems to have been the main mechanism of infestation by adult bugs in this area, and a total of $51 \%$ of the surveyed inhabitants reported that the insects had flown into their flats.

Key words: Triatoma infestans - urban areas - dispersal flight - San Juan - Argentina

Triatoma infestans (Hemiptera, Reduviidae) is an important domestic vector of Chagas disease in Argentina and neighboring countries, typically occupying cracks and crevices in poor quality rural dwellings and emerging at night to suck the blood of people and domestic animals. Immature stages and adults can be dispersed by passive carriage, sometimes over long distances, in the clothes and luggage of people travelling from one house to another (Soler et al. 1969, Dias 1979, Schenone et al. 1980, Schofield 1988). Adult bugs can also disperse by active flight, although the average flight range is usually not more than 200-2000 m (Lehane \& Schofield 1976, 1981, Ward \& Baker 1982, Schweigmann et al. 1988, Schofield et al. 1992). Other species of Triatominae have been found passively carried by birds (Gamboa 1962), however this has not been reported for T.infestans.

Although usually associated with rural habitats, T.infestans has also been reported from some periurban districts, and, in the city of San Juan, has been found in homes and public buildings in the centre of the city. In the province of San Juan, when the "Zonda" blows (a warm wind blowing from the west) the inhabitants say it is common to see the arrival of adult T.infestans flying into their homes. This phenomenon, known locally as the "chinches" flight (local term, Vallvé et al. 1991)

${ }^{+}$Corresponding author. Fax: 54-64-213672

Received 20 March 1995

Accepted 6 March 1996 has long been noted in rural areas (Schweigmann et al. 1988, Vallvé et al. unpublished data) and has been increasingly seen in urban areas. During the last five years the Servicio Provincial de Chagas of San Juan has received many requests for insecticide spraying of urban buildings as a result of the confirmed presence of T.infestans in homes and public buildings in the city of San Juan.

This paper describes a survey of a housing complex in central San Juan where there have been numerous reports of T.infestans, and attempts to determine the mechanism by which the buildings have become infested.

\section{MATERIALS AND METHODS}

Study area - This study was performed in an urban area of San Juan, capital city of the province of San Juan in the western part of Argentina $\left(31^{\circ} \mathrm{S}\right.$, $\left.68^{\circ} \mathrm{W}\right)$. It is located in one of the driest continental regions of this country, with a mean annual precipitation of $96 \mathrm{~mm}$ and mean annual temperature of $18^{\circ} \mathrm{C}$. Summer maximum temperatures rise up to $45^{\circ} \mathrm{C}$, the minimum goes down to $-7^{\circ} \mathrm{C}$ (Reta 1979).

San Juan is a seismic area where city houses are built with reinforced concrete, light bricks or hollow blocks and a system of enchainment of iron columns. In the province pigeons are a common pest and usually colonize abandonned buildings which became useless after earthquakes.

The selected area corresponds to Barrio San Martín housing complex (Fig. 1-a), in the northern capital district, which had more than 2600 people for 15 years $(2.2 \%$ of the total population 
of the Capital Department). T.infestans has frequently been reported from flats in the housing complex. During 1989 for example, $7 \%$ of the requests for insecticide sprayings (of the Capital Department to the Local Control Agency) came from the studied neighborhood.

The buildings of the housing complex are within an area of 8 ha and there are 768 flats distributed in seven towers ( $\mathbf{T})$ of seven floors each, six inter-towers (it) and six sections (S) of three floors each (Fig. 1-a), surrounding a large area with an abandoned central winery (Fig. 1-c). On the roof, inside the winery and on the terraces of some buildings there were large pigeon colonies.

The seven-floor-buildings are divided into two semi-towers of flats joined by a bridge every two floors and a central elevator. The terraces are covered with longitudinally cut half-blocks (a hollow brick - 15 x $40 \mathrm{~cm}$ - made of cement with an air carpet below) (Fig. 1-b) in order to provide insulation from heat and rain. On top of these half-blocks nest a great number of pigeons.

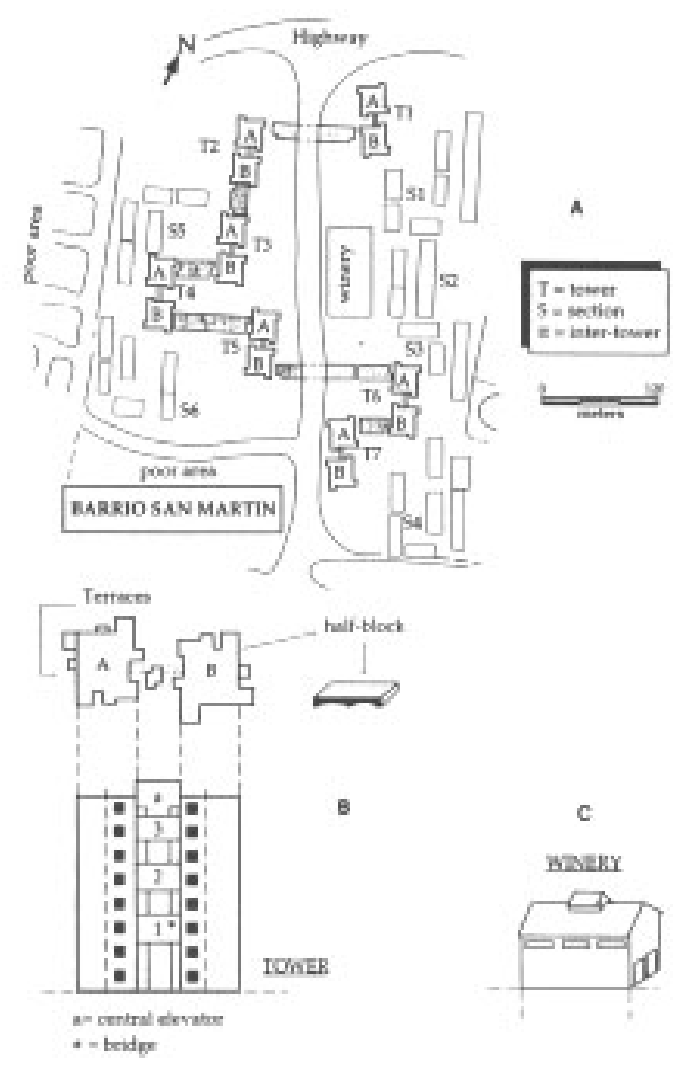

Fig. 1 - A: distribution of the buildings of the housing complex in the Barrio San Martín. B: detail of the tower and the half-blocks carpeted the terraces. C: winery.
The whole housing complex is surrounded by groups of poor dwellings at distances that range from 2 to $200 \mathrm{~m}$. About $200 \mathrm{~m}$ northwards there was a small group of mud and tin houses - ranchos - called "Villa San Francisco" and separated from Barrio San Martín by a highway.

To fullfill a special request made by the inhabitants, an entomological survey was carried out in the terraces of the buildings, the abandoned winery and the nearby poor houses. Many specimens of T.infestans were found in terraces, the winery and the poor houses and all infested places were immediately treated with insecticides (results published separately, Vallvé et al. 1995).

House surveys - A questionnaire was randomly performed in 256 flats out of 768 (33.3\%). The inhabitants were asked about the number of times they had found bugs inside their homes, their stage - adult or nymph -, where had they come from and how those insects had entered their houses. The dwellers were trained to capture and keep the triatomines they found.

Laboratory studies - All collected triatomines were identified and classified according to instar and the adults were sexed. The presence of Trypanosoma cruzi was determined by microscopical observation of the feces of each insect (400x). The intestinal contents of each triatomine was kept at $-22^{\circ} \mathrm{C}$ for its subsequent identification of blood meal sources (Wisnivesky-Colli et al. 1982).

\section{RESULTS}

Inhabitants'reports on triatomine findings The Table summarizes the reports of insects captured or killed by flat dwellers during this present study in 1993 (November-December). From the 28 collected insects, $24(86 \%)$ were adults that had been captured while flying in through the windows on windy days. The sex ratio of collected bugs was 1:1 (M:F). Only one out of the 28 T.infestans was infected with T.cruzi. Adult triatomines were recorded on all floors. Only four (17\%) of the collected insects had identifiable blood meals in their guts, the remainder were starved. The four triatomines containing blood (two males, one 5th instar and one 4th instar nymph) had fed on humans.

During the survey, $130(50.8 \%)$ out of the 256 questioned people, reported that one or more adults of T.infestans had flown into their flats. T.infestans was never observed in $36.3 \%$ of the flats (93/256) but was found at least once - flying or resting on walls or in beds - in $63.7 \%$ of the flats (163/256).

Fig. 2 shows the proportions of 256 surveyed flats with negative, single or multiple bug reports of T.infestans per floor of each tower. It can be 


\section{TABLE}

Triatoma infestans findings (reported or captured) by the inhabitants during the survey performed in Barrio San Martín, November-December 1993, Capital Department, Province of San Juan, Argentina

\begin{tabular}{|c|c|c|c|}
\hline Buildings & Floors & Instar & Observations \\
\hline Tower 1 & G.F., $2,5,6$ & 5 adults $(2 \mathrm{~F}, 3 \mathrm{M})$ & have flown into the room \\
\hline Tower 3 & 7 & 1 adult $(1 F)$ & wall crevices \\
\hline Tower 4 & 4,6 & $\begin{array}{l}2 \text { nymphs }(\mathrm{N} 3, \mathrm{~N} 5) \\
2 \text { adults }(1 \mathrm{~F}, 1 \mathrm{M})\end{array}$ & $\begin{array}{l}\text { in bed or matresses } \\
\text { flying in during night }\end{array}$ \\
\hline Tower 5 & 5 & 1 adult $(1 \mathrm{~F})$ & \\
\hline Tower 6 & $2,5,6,7$ & 5 adults $(3 \mathrm{~F}, 2 \mathrm{M})$ & starved bugs \\
\hline Tower 7 & $3,5,7$ & $\begin{array}{l}3 \text { adults }(1 \mathrm{~F}, 2 \mathrm{M}) \\
1 \text { nymph }(\mathrm{N} 2)\end{array}$ & "Zonda" was blowing \\
\hline $\begin{array}{l}\text { Sections } \\
1,2,4,6^{a}\end{array}$ & 1,2 & $\begin{array}{l}7 \text { adults }(3 \mathrm{~F}, 4 \mathrm{M}) \\
1 \text { nymph (N5) }\end{array}$ & $\begin{array}{l}\text { during hot wind resting on metalic net } \\
\text { oviposited inside jar }\end{array}$ \\
\hline Total & & $\begin{array}{l}24 \text { adults }(12 \mathrm{~F}, 12 \mathrm{M}) \\
4 \text { nymphs }(\mathrm{N} 2, \mathrm{~N} 3, \mathrm{~N} 4, \mathrm{~N} 5)\end{array}$ & \\
\hline
\end{tabular}

a: unique T.infestans (F) with Trypanosoma cruzi

F: female; M: male

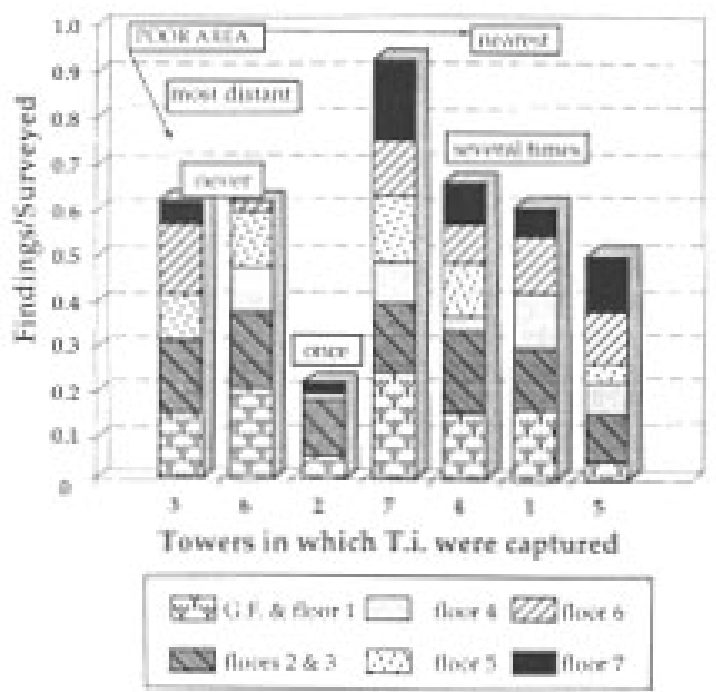

Fig. 2: proportions of 256 surveyed flats with negative, single or multiple reports of Triatoma infestans per floor each tower, Barrio San Martín, 1993, San Juan, Argentina.

noted that most multiple findings corresponded to tower $7(31 / 33,94 \%), 4(22 / 33,67 \%), 1(19 / 31$, $61 \%)$ and $5(21 / 42,50 \%)$ which are closest to the nearby poor houses.

The analysis of the proportion of flats with multiple findings for all the towers, grouped for each floor (Fig. 3) shows similar percentages for either lower (G.F. and 1st: 67\%, 2nd and 3rd: $73 \%$ ) or higher floors (6th: 53\% and 7th: 58\%).

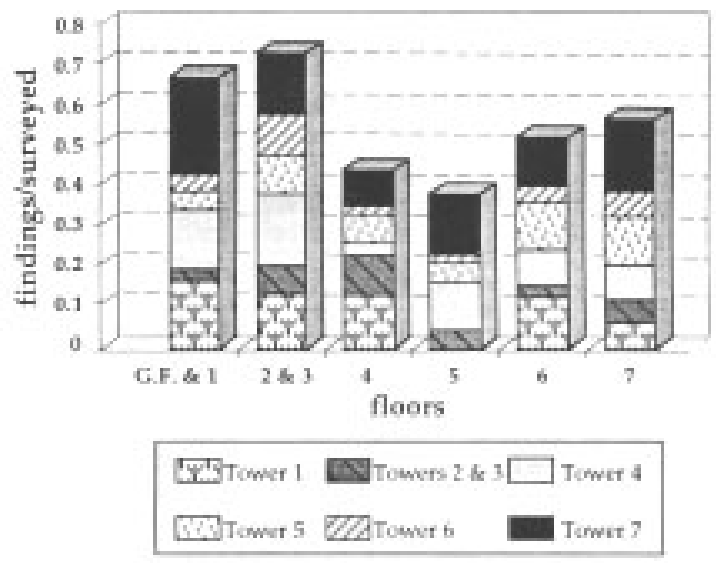

Fig. 3: proportions of 130/256 surveyed flats with multiple findings of Triatoma infestans for all the towers grouped for each floor, Barrio San Martín, 1993, San Juan, Argentina.

\section{DISCUSSION}

Considering T.infestans collections and reports obtained by means of the inquiries, it is evident that the presence of adult T.infestans was very frequent, on all floors. Therefore, flight dispersal seems to be of great epidemiological importance in this studied area since flying females could initiate new colonies in nearby houses from a preexistent focus. In this sense it is worthwhile mentioning that an inhabitant captured an adult female which had entered his house one or two days before and oviposited inside the collecting jar. The 
triatomine colonies detected in the terraces and winery could have acted as those foci. There is an apparent relationship between the higher frequencies of T.infestans occurrence and the proximity to the poor housing areas. Other studies are necessary to establish if this neighbor area could act as external infestation foci for the studied neighborhood.

There is enough evidence to postulate that infestation of flats is made by adult T.infestans flying inside the buildings: 24 out of 28 T.infestans captured by the inhabitants were adult and half of them females; the finding of nymphs were always associated with previous reports of the entrance of flying adults; $64 \%$ of the people had captured some T.infestans at least once in their houses; triatomine findings occurred on all floors; $50 \%$ of the surveyed flats reported adult insects flying indoors when the "Zonda" was blowing; those insects caught were depleted of blood as it has been recorded for dispersing adults (Schofield 1985); and those two adult T.infestans that rendered positive in the tests had recently fed on human blood.

\section{ACKNOWLEDGEMENTS}

To Carlos Atencio, Miguel Guerra and Roberto Guevara from the "Municipalidad de la Capital de San Juan" for technical assistance and to Bea Ferrer and María Mercedes Quel for helping with the English version of the manuscript.

\section{REFERENCES}

Dias JCP 1979. Mecanismos de transmissão em Trypanosoma cruzi e Doença de Chagas, p.152-174. In Z Brenner, Z Andrade (eds), Guanabara Koogan, Rio de Janeiro.

Gamboa J 1962. Dispersion del Rhodnius en Venezuela. Bol Dir Malar y San Amb 3: 262-272.

Lehane MJ, Schofield CJ 1976. Preliminary report on flight by some triatomine bugs. Trans $R$ Soc Trop Med Hyg 73: 273-283.

Lehane MJ, Schofield CJ 1981. Field experiments of dispersive flight by Triatoma infestans. Trans $R$ Soc Trop Med Hyg 75: 399-400.
Reta AJ 1979. Descripción del Agro-clima de San Juan. INTA(Instituto Nacional de Tecnología Agropecuaria), Servicio de Agrometeorología, San Juan, 24pp.

Schenone H, Villarroel F, Rojas A, Alfaro E 1980. Factores biológicos y ecológicos en la epidemiología de la enfermedad de Chagas en Chile. Bol Chile Parasit 35: 42-54.

Schofield CJ 1985. Population dinamics and control of Triatoma infestans. Ann Soc Belge Med Trop 65: 149-164.

Schofield CJ 1988. Biosystematics of the Triatominae (Hemiptera:Reduviidae) and their significance as vectors of Chagas'disease. Bull Am Mus Nat Hist 163: 123-250.

Schofield CJ, Lehane MJ, McEwen P, Catalá SS, Gorla DE 1992. Dispersive flight by Triatoma infestans under natural climatic conditions in Argentina. Med Vet Entomol 6: 51-56.

Schweigmann N, Vallvé S, Muscio O, Ghilini M, Alberti A, Wisnivesky-Colli C 1988. Dispersal flight by Triatoma infestans in an arid area of Argentina. Med Vet Entomol 2: 401-404.

Soler CA, Schenone H, Reyes H 1969. Problemas derivados de la reaparición de Triatoma infestans en viviendas desinsectadas y el concepto de reinfestación. Bol Chile Parasit 24: 83-87.

Vallvé S, Schweigmann N, Petersen R, García Piñeiro C, Travaini A, Vazquez F, Solarz N, WisniveskyColli C 1991. Presencia de Triatoma infestans en relación con algunas características culturales de una población rural de la Provincia de San Juan, Argentina. Bol Chile Parasit 46: 7-14.

Vallvé SL, Rojo H, Wisnivesky-Colli C 1995. Ecología urbana de Triatoma infestans en Argentina. Asociación entre Triatoma infestans y palomares. Rev Saúde Pública 29: 192-198.

Ward JP, Baker PS 1982. The tethered flight perfomance of a laboratory population of Triatoma infestans (Klug) (Hemiptera:Reduviidae). Bull Entomol Research 73: 17.

Wisnivesky-Colli C, Gürtler RE, Solarz N, Salomon D, Ruiz AM 1982. Feeding patterns of Triatoma infestans (Hemiptera:Reduviidae) in relation to transmission of American Trypanosomiasis in Argentina. J Med Entomol 19: 645-654. 